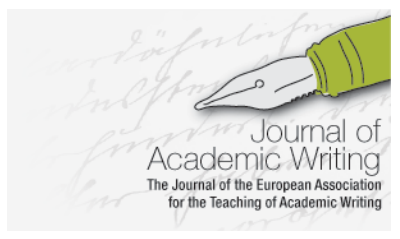

Journal of Academic Writing Vol. 11 No 1 Summer 2021, pages 45-61 https://doi.org/10.18552/joaw.v11i1.566

\title{
L2 Learners' Perceptions of Their Writing Strategies on an Intensive EAP Course
}

\author{
Diana Mazgutova \\ University of Leeds, UK \\ Judith Hanks \\ University of Leeds, UK
}

\begin{abstract}
This study examines second language (L2) learners' perceptions of their writing strategies on an intensive English for Academic Purposes (EAP) programme at a British university. The participants were 14 Chinese pre-undergraduate students who engaged in interviews and completed reflective journal entries. The results of the analyses indicate that after four weeks of studying on the EAP course, students believed that they started to apply a broader range of writing strategies, such as reading extensively, using exemplars of student writing to inform their own assignments, revising in a more focused manner and appreciating tutor feedback on their writing. Thus, the perceived increase in the use of various writing strategies is indicative of the potential effectiveness of a short EAP pre-sessional course.
\end{abstract}

\section{Introduction}

Academic writing skills are indispensable for L2 learners at university (Pecorari, 2006). Since students' success is often determined by their performance in written assignments, writing constitutes a core academic skill. The importance of writing is also reflected in the emphasis given to this skill on pre-sessional EAP programmes at British universities. Hence, students who do not attain the minimum English language test score needed for entry into university may receive an offer of study on the condition of completing an EAP course. The value of EAP instruction has been clearly demonstrated in SLA and writing research (Evans \& Green, 2007; Hyland, 2016; Reid, 2001; Storch \& Tapper, 2009; Zhu, 2004). Although EAP courses might focus on improving learners' levels of English language proficiency (Hyland \& Hamp-Lyons, 2002), their ultimate aims lie in equipping learners with relevant academic and study skills (Hanks, 2015, 2017; Mazgutova \& Kormos, 2015) as well as familiarising them with academic writing genres. Importantly, writing strategies have been considered to be instrumental in assisting L2 learners to expand their writing skills.

This study contributes to academic writing research by offering insights into the self-reported changes in L2 learners' writing strategies on a four-week EAP course. Specifically, some underinvestigated writing strategies such as extensive reading of the literature, use of exemplars of students' writing, seeking tutor's support and revising and backtracking are discussed in this paper. An important methodological contribution of our study for the fields of L2 writing, EAP and SLA lies in its use of two data collection methods, i.e., semi-structured interviews and reflective learning journals, to be able to gain insights into the nature of L2 learners' selfperceived writing strategies on a pre-sessional course. 


\section{The Value of Writing Strategies}

Over recent years, research on L2 writing and academic writing (Bitchener, 2017; Ferris, 2010, 2017; Hyland, 2016; Manchón, 2012; Paltridge, 2014, 2017; Tardy, 2017) has grown rapidly. Some studies (e.g., Bitchener, 2017; Bitchener \& Basturkmen, 2006) have shown that studentwriters perceive language-related aspects of writing such as grammatical accuracy, clarity of ideas, cohesion and appropriacy of writing style to be more challenging than content and organisation-related aspects of writing. However, other researchers' findings have demonstrated the opposite trend (e.g., Kubota, 1998; Marshall, 1991). In the process of writing, students should try to identify ways of enhancing their own learning by applying certain learning strategies for successful academic achievement.

Learning strategies are described as "specific actions taken by the students to make learning easier, faster, more enjoyable, more self-directed, more effective, and more transferable to new situations" (Oxford, 1990, p. 8). In addition to the research into general learning strategies (Manchón, 2001; Oxford, 2016; Zhu, 2001), studies have been undertaken to address the strategies specific to L2 writing (Csizér \& Tankó, 2015; Manchón, 2017; Mu \& Carrington, 2007; Roca de Larios et al., 2016). Several studies have shown relationships between writing competence and writing strategies. According to Manchón (2001), more and less successful writers were found to differ in their use of writing strategies and successful writers tend to use a wider variety of strategies than less successful ones. Writing strategies appear to be essential because they help writers monitor the processes of writing and learning as a whole (O'Malley \& Chamot, 1990). Among the numerous strategies used by the L2 writers, i.e., rhetorical, cognitive, metacognitive and social, this study mainly focused on more widely used cognitive and social strategies because, as the interview and learning journal data suggests, these two kinds of writing strategies were predominantly reported to be used by the students in our study.

Cognitive strategies are linked with the mental processes involved in referring to background knowledge, making assumptions and drawing inferences (Khaldieh, 2000). For example, a cognitive strategy of backtracking involves rescanning the text written to get access to lexical items and deciding on whether those match the context of the essay. Manchón, Murphy and Roca de Larios (2007a) point out that backtracking is used by writers not only during the composition process but also during the revision process. Social strategies (Huang, 2013; Guo \& Huang, 2018), or as Oxford (2016) identified them, sociocultural-interactive learning strategies, are normally chosen by the L2 writers to interact with other people, e.g., tutor or peers, to reduce anxiety and boost motivation. Engaging students in examining citation practices of other writers and of their peers might help to "raise their metacognitive awareness of citing", reflect on their own citation behaviour and, ultimately, improve their academic writing ability (Petrić \& Harwood, 2013, p. 121). As suggested by Leki and Carson (1994), although L2 writers sometimes ask their classmates for assistance, they particularly value tutor feedback.

Several studies have focused on examining writing strategies of L2 writers (Manchón et al., 2007a; Manchón, Roca de Larios \& Murphy 2000, 2007b; Myhill \& Jones, 2007), but no research to date appears to have been conducted in the context of highly intensive EAP programmes, and little is known about the impact of these programmes on learners' writing behaviours and perceived writing strategies. This study therefore attends to this gap by addressing the following research question: What were the L2 learners' perceptions of their own writing strategies at the beginning and at the end of the pre-sessional EAP programme?

\section{Methodology}

This study was part of a larger project using a convergent parallel mixed method. A key characteristic of this method is the concurrent integration of quantitative and qualitative forms of data by combining them (Creswell, Plano Clark, Gutmann \& Hanson, 2003; Creswell \& Plano Clark, 2011). In the project, both quantitative and qualitative data were collected concurrently and analysed independently before being brought together for triangulation. In a sister paper, Mazgutova and Kormos (2015) discuss the quantitative data, focusing on the students' written work from the point of view of syntactic complexity and lexical sophistication. In order to provide 
much-needed depth of exploration of students' perceptions of writing strategies, this methodology first introduces the research setting and participants, then describes our qualitative research tools, and finally explains the data analysis procedures used in our study.

\section{A. Setting and participants}

The research was conducted on an intensive four-week pre-sessional EAP programme offered by a university in the UK. The aims of this programme, in common with many across the country (see, for example, Hanks, 2015, 2017), were to:

- develop students' use of English in an academic context

- foster critical thinking

- cultivate an awareness of the learning skills and strategies they might use while studying in a British university environment

The EAP programme was targeted at students with the International English Language Testing System (IELTS) scores of 5.5 to 6.5 (B1 to B2 levels on the Common European Framework of Reference (CEFR), Council of Europe 2001) who received a conditional offer from their university because their level of English did not meet the minimum entry requirements. During the EAP course, students had 15 hours of instruction per week and, additionally, were expected to study at least 15 hours a week independently. Every student was offered four one-to-one tutorials conducted weekly, during which they were given feedback on their writing. The individual tutorials were offered weekly as part of the pre-sessional programme and were conducted by the class tutor.

The pre-sessional programme comprised three modules Academic Reading and Writing (ARW), Listening, Reading and Discussion (LRD), and Oral Presentations (OP). ARW was the core module because in our local context reading and writing skills are often believed to be the most difficult to master and yet have the greatest impact on students' performance at the university. The aim of the ARW module was to develop students' use of English in an academic setting. The objectives involved helping students to raise their awareness of the writing process, create coherent and structured texts, assess credibility of academic sources, and develop their confidence as writers. While studying on the EAP programme, once a week prior to submission of their own assignments, students were introduced to some exemplars of former EAP students' writing of exceptionally high quality, which were expected to assist them with their own writing. Students' performance on the programme was evaluated formatively by means of weekly writing assignments, which took the form of argumentative essays. These increased in complexity over the four weeks. After students completed an assignment, they received written feedback from their tutor, which focused on various aspects of writing. Teachers wrote commentaries on Task Response, i.e., relevance of the content and persuasiveness of argumentation, Organisation, i.e., sequencing of ideas, and Use of Source Material, i.e., adherence to referencing conventions. They also gave feedback on Language Use by highlighting repeated errors in the essays. Besides receiving written feedback from their tutor, all students on the EAP course were eligible to attend one-to-one tutorials conducted weekly. The tutorials were offered as a form of additional support with specific aspects of students' academic writing.

A group of 14 newly arrived Chinese pre-undergraduate students from one cohort volunteered to participate in our study. The participants were asked to sign the consent form, informing them about their rights. They were not obliged to answer any questions, and they were free to withdraw from the study at any time if they felt uncomfortable.

Students needed a minimum of band 6 on IELTS with not less than 6 in any component to join the pre-sessional course. Table 1 summarises their background data. The students were planning to study one of the following disciplines upon completion of the EAP programme: Business Studies (three students), Economics (two students), Accounting and Finance (seven students) or Media and Cultural Studies (two students). Participants had no prior experience of living abroad, and all acknowledged having had only limited experience of academic writing. 
Table 1.

Student profiles

\begin{tabular}{ll}
\hline Gender & 2 male and 12 female \\
Age range & $18-21$ \\
L1 background & Chinese \\
Number of years learning English & Approximately 10 \\
\hline
\end{tabular}

\section{B. Interviews}

Semi-structured interviews, considered to be the most in-depth interview form in language education (Mann, 2016; Nunan, 1992; Richards, 2003; Whiting, 2008), were conducted with participants in order to "probe and expand the interviewees' responses into any emerging topics" (Rubin \& Rubin, 2005, p. 88) and to examine in greater depth students' perceptions about their writing strategies (Kvale, 2003).

Each interview lasted approximately 25-30 minutes. Each student was interviewed twice - at the beginning of Week 1 and at the end of Week 4. See Appendix A for the list of interview questions. Some prompts used were as follows: "What is your usual method of writing in English? What steps do you follow when writing?" (interview prompt in Week 1) and "Has your method of writing in English changed in 4 weeks? What steps do you follow now when writing?" (interview prompt in Week 4).

Having been taught various writing strategies on the EAP programme and having had approximately ten years of English language learning experience, the students were able to fluently express themselves and were expected to be able to reflect on their own writing strategies. According to Mann (2016), an interview might be conducted in the interviewee's L2 when the interviewer and the interviewee "do not share the same L1 but the interviewee is competent in what is their L2" (p. 218). Therefore, conducting interviews in English was not a problem. Additionally, as indicated by the participants and pointed out in Hanks (2015), "there was an added benefit for the learners: extra opportunities to practise the language they had come to the United Kingdom to study" (p. 120).

\section{Learning journals}

The interview data was complemented by non-assessed learning journals (Borg, 2001; Threlfall, 2014; Wallin \& Adawi, 2017), which all 14 participants were invited to complete as part of the study. One of the advantages of learning journals as opposed to observations or thinkaloud protocols is their non-intrusive nature (Cathro, O'Kane \& Gilbertson, 2017). Assuming students might be nervous in an interview, we chose to use learning journals as an additional method of data collection which does not involve face-to-face contact with the researcher and does not set rigid time restrictions. Participants were asked to keep an accurate and detailed account of their thoughts regarding their writing by completing one reflective entry per week starting from the end of Week 1 and up to the end of Week 3 on the EAP programme. No word limit was imposed, but entries ranged from 600 to 700 words. Despite being an extra burden for students, learning journals were expected to promote students' self-reflection, foster their critical thinking and ultimately enable them gain better insights into their own learning (Borg, 2001). Some of the questions the participants were invited to respond to in their learning journal entries were as follows: "Did you use any particular writing strategies when writing your essay? Did you ever get stuck while writing? What did you do to get 'unstuck'/to find the way out?" See the full list of learning journal prompts in Appendix B.

\section{Data analysis}

The data were manually coded and analysed by two researchers, and a consensus was reached on the interpretation of the data (Creswell \& Plano Clark, 2011). We used coding, which, according to Taylor and Gibbs (2010), is one of the most important instruments of thematic analysis consisting of breaking down text into manageable units. The coding of the interviews and learning journals was carried out in accordance with the standard practice on 
thematic analysis by 1 ) identifying themes and subthemes; 2 ) selecting important themes and subthemes; 3) establishing theme hierarchies; and 4) linking themes and subthemes to theoretical frameworks (Ryan \& Bernard, 2003). The ideas and concepts representing subthemes, which would underpin one of the main themes, were highlighted. To identify the themes and subthemes in our data, we applied the so-called pawing or eyeballing technique (Bernard, 2000). This process involved reading the interview transcripts and learning journal entries at least two or three times, highlighting the texts with different coloured markers, underlining the key words, and drawing lines and arrows to indicate various meanings (Bryman, 2003; Ryan \& Bernard, 2003). Having done that, we started looking for patterns and trends (see Appendix $C$ for a coded transcript). Criteria for the theme selection were as follows: 1) repetition of key words and phrases; 2) unusual or unexpected items; 3) themes contrary to own expectations; and 4) themes contrary to literature.

One of the authors of this paper did the initial coding of the whole data set and, following this, half of the data was coded by a second coder, who was a postgraduate researcher in Language Education. We felt that this was a sufficiently large sample for the purposes of getting accurate agreement statistics. The interrater reliability (Cohen's kappa) for the coding of the interview data was 0.75 , and 0.87 for the learning journals, which according to Landis and Koch (1977) signifies excellent agreement.

\section{Findings and Discussion}

The research question addressed in this study was related to determining the writing strategies used by the participants during the EAP course. The results of the analyses demonstrated that students increased the use of the following writing strategies: extensive reading of the literature; using exemplars of student writing; rereading essays multiple times; and appreciating tutor feedback on their writing. However, the students' perceived use of revision for language accuracy has notably decreased by the end of the pre-sessional course.

\section{A. Engaging in extensive reading}

One of the biggest changes observed in students' perceptions of their writing strategies was their notably increased engagement in extensive reading of academic literature. Although only six participants mentioned extensive reading in Week 1 of the EAP course, in Week 4, 12 of 14 stated that they began to read a range of sources related to their area of study. Student 1 states "My major is economics, so I will read more essay, papers or other materials related to my subject..." and suggested that this strategy was conducive to the development of their academic writing skills: "this should help me so much to improve my writing ability" (interview 2). Reading extensively was viewed by the students as one of the effective ways to generate ideas for their assignments (see Mu \& Carrington, 2007). The lack of mention in the Week 1 interviews, suggests that students were initially unaware of the value of reading extensively as a writing strategy. Research shows that in the L2 writing class, reading provides learners with language development opportunities and scaffolding as well as meaning and ideas to use in their own writing (Bitchener, 2017; Hinkel, 2004).

Another value of extensive reading lies in the potential for enrichment of academic vocabulary. Participants in our study claimed they had learnt a substantial amount of academic words and expressions by reading widely, e.g., "I find it difficult to find academic words for my essays...I will read more academic writing" (Student 3, interview 2). Furthermore, reading other people's writing might aid substantially in developing critical reading and reflection skills. Thus, the following was reported by a student in their learning journal entry:

Sometimes the ideas can make me stuck. It's hard to find out some critical and creative ideas in a short time. The problem could be solved with more reading and practice to see how other people show their ideas when they are given the topic and learn something from their writing. (Student 2, journal 1)

Thus, the findings of our study have shown that through reading, the students have become familiar with academic register, begun to develop their lexical repertoire and learnt to accurately 
use complex syntactic structures in their assignments. While reading, students might encounter not only a range of themes but also a variety of lexical and syntactic structures, which they can then adapt in their own writing (Phakiti \& Li, 2011). Hence extensive reading of appropriate material is likely to contribute to some improvement in students' academic writing.

\section{B. Use of exemplars}

Another noteworthy change in students' perceptions of their writing strategies was an increase in the strategy of using exemplars of student work. While none of the participants mentioned that specific strategy at the beginning of Week 1, five learners acknowledged reading good examples of students' work in Week 4 of the EAP programme. They reported that familiarising themselves with others' writing aided them substantially in developing their critical reading and reflection skills. For example, during the Week 4 interview, one of the students stated:

I will try to write something maybe imitate I mean read an essay ... a good essay about our major, I will try to imitate the writing style and use ... select the useful words [pause] or expressions and then when I write something next time take a note of words or expressions [laugh] I don't know whether I need to make a reference ... I really agree imitate is a good way for international students to improve their writing in English yeah because they can know more about words about the way of writing. (Student 14, interview 2)

This small increase (from none to five) in perceived use of exemplars of students' writing might suggest that studying on the EAP programme enabled students to realise the usefulness of reading other students' essays for their own writing progress.

Overall, it appears that learners should be encouraged to read well-written exemplars of student work, with a focus on organisation, coherence and academic language use since doing so helps them to form their own position and, overall, be well-prepared for academic writing.

\section{Revising and backtracking}

Another interesting finding to emerge from our study is that the number of students using the perceived writing strategy of revision for grammatical accuracy has decreased from Week 1 to Week 4 on the EAP course.

Prior to their studying on the pre-sessional course, 5 of 14 students employed the cognitive strategy of revising their essays for grammar. As noted in Week 1, "When checking I will read my essay from the beginning to the end and read word by word and check grammar mistakes and others. First, I will begin with grammar because my grammar is not very good" (Student 13, journal 1). At the end of the EAP programme, the number of students who focused predominantly on grammar when editing their writing declined to one. After having studied on the EAP course for four weeks, learners seemed to have become better aware of the importance of revising their writing for meaning with the aim of maintaining the coherence of the argument.

It appears that to concentrate more on ideas, students seemed to postpone their focus on linguistic errors: "Before I check grammar and other mistakes, I will check that the Introduction contains my position and the main point and goals, I mean the task" (Student 5, interview 2). This behaviour may stem from the writers' intention to concentrate on the flow of thought and coherence of ideas rather than on individual grammatical and lexical flaws (Myhill \& Jones, 2007). It could be inferred that despite a rather limited explicit focus on linguistic accuracy on the EAP programme, learners' grammar has improved from reading extensive literature and engaging in various writing activities.

Backtracking, i.e., rereading the assignment from the beginning to the end a number of times, is widely recommended as a strategy (Manchón et al., 2000). However, most students did not mention it during the first week of the EAP course. By the end of the course, backtracking was more widely reported by the participants. The results of the analysis have shown that numbers of learners who reported on having applied the backtracking strategy doubled over the course of four weeks (increased from four in Week 1 to eight in Week 4). Reflecting on their revision 
strategies, one student commented in the Week 4 interview: "I actually read the essay again and again because there are some mistakes concealed so maybe at first sight we cannot find them so you should read again and them you could find them" (Student 1, interview 2).

According to Myhill and Jones (2007), backtracking aids writers when it comes to generating ideas. When students read through the essays the second time, they can reflect on what they have written and consider the coherence of their ideas and whether the ideas are sufficiently clearly expressed as to be interpretable by the reader (see Silva, 1993). Our findings have demonstrated that reading back over what has been written assisted the students considerably in the process of evaluation and editing of their own writing assignments. In the process of rereading, student-writers might attempt to resolve the problems with, for example, lexical search and retrieval (Manchón et al., 2007a).

\section{Seeking tutor support}

Tutorials with teachers are an integral part of any EAP pre-sessional programme, and this fourweek course was no different. Students gradually developed trusting relationships with their tutors and began to incorporate feedback into their writing. The results of the data analysis suggest that the majority of students, i.e., 11 of 14 at the end of the programme (as opposed to only 5 of 14 at the beginning), highly appreciated written and oral tutor feedback and tended to discuss various aspects of their academic writing during one-to-one tutorials which were organised not by the researcher, but by the EAP programme tutor. The tutorials were conducted every week after the assignment submission deadline.

As one student said at the end of the EAP programme: "After the tutorial, I will read the assignment again, rewrite some parts of my essays and hand it in to my teacher, and she will reread and give some of her valuable ideas, suggestions and I can improve next time" (Student 12, interview 2). The analysis shows that throughout the EAP course, students were not confident enough in their ability to revise their writing. Having reread their assignments, they employed a sociocultural strategy, i.e., addressed their tutor for help. Such sociocultural interactive strategies seem to facilitate students' general and academic writing, as indicated by Oxford (2016).

Researchers claim that interaction with others aids learning and facilitates improvement in writing (Leki \& Carson, 1994, Mu \& Carrington, 2007). The number of students who preferred to address their tutors for feedback increased considerably over the course of four weeks on the programme. One of the likely reasons for teacher feedback being popular among L2 writers at the end of the EAP course is the expertise, knowledge and skill that the teachers are assumed to possess. The participants of this study, as in Leki and Carson's (1994) study, noted that receiving teacher feedback is critical for their development as academic writers because it tends to be comprehensive (unlike the feedback they get from peers) and balanced, i.e., focused on both strengths and weaknesses. The latter was emphasised as particularly essential since teachers, who are seen to be skilled writers themselves, can give suggestions for further improvement.

\section{Limitations and Directions for Further Research}

This study has provided a greater depth of understanding of students' perceptions of their own writing strategies. Our qualitative stance here means that we were not attempting to generalise the research outcomes to specific culture, nationality or gender, but rather to gain insights into learners' perceived writing strategies used at the beginning and at the end of the EAP programme. However, perceptions are notoriously difficult to access, and we acknowledge that we reported what the students felt willing to convey to us in a relatively short space of time. In future research, a longer period (e.g., following up participants in their parent departments after the pre-sessional has ended) might yield helpful data for charting the changes in students' perceived writing strategies over time. Although we did not evaluate the observed use of the writing strategies in this study, we attempted to offer insights into the types of strategies learners appear to develop that can be used to inform teaching practice and offer insights into EAP programmes which are largely under-investigated. 
The study might also be viewed as limited in that during the interviews and in the learning journals, the participants L2 rather than L1 was used. It should be acknowledged that since students tend to be more competent in expressing themselves in L1, using Chinese in interviews and journals might have helped to elicit a deeper understanding of their cognitive processes and experiences. Two primary reasons for choosing to use English rather than Chinese were as follows: 1) the interviewer and the interviewees did not share the same L1 and the interviewees were able to express their thoughts in English without major difficulties (Mann, 2016); and 2) using English would enable students to further practice their target language (Hanks, 2015).

An additional uncontrolled factor in our study is the possibility of biases arising from students performing social acceptability in their learning journals and interview responses. The participants might have been trying to guess what we wanted to hear from them and, therefore, were likely to provide 'display' writing in the learning journals and 'display' responses in the interviews.

Finally, although our study did identify the changes in the students' perception and use of writing strategies over the course of four weeks and the likely causes from the syllabus, it is not possible to fully identify all the factors contributing to these changes.

It might be interesting in the future to investigate the relationship between learners' perceived writing strategies, their writing difficulties and the use of syntactic, lexical and cohesive features of their writing. This would offer insights into the factors that might affect learners' perceptions and assessment of their own difficulties in academic writing. It could also be useful to conduct multiple case studies to investigate writers' linguistic and cognitive development in-depth. Finally, one other possible research direction might be to examine whether student writers use the same writing strategies in naturalistic contexts, i.e., where they are not required to write an essay within a restricted time. Such research might provide considerable insights into writing processes and inform second language writing research.

\section{Conclusion}

Second language learners are likely to get frustrated if they lack strategies to help them accomplish a task (see Wolfersberger, 2003). The current study was focused on examining the L2 learners' perceptions of their own writing strategies at the beginning and at the end of the pre-sessional EAP programme. The findings suggest that L2 learners have reported positive changes in their writing strategies both by acquiring some effective strategies and decreasing the use of less effective ones, over the duration of a short pre-sessional course. It can thus be concluded that the EAP programmes can help equip students with requisite strategies.

To produce well-written essays, learners should develop awareness of academic register in English and be equipped with various writing strategies. Specifically, our study finds that students should be taught to read extensively and teachers should consider directing their students to academic books, scholarly journals, professional magazines and educational websites, which could assist them substantially with enriching their lexicon in English as well as using scholarly ideas to support and challenge their own arguments. Our findings also suggest that the use of exemplary academic essays produced by other learners might assist students by serving as a model of skilful writing and enable them to attempt to improve the academic style, clarity, cohesion, and linguistic accuracy of their texts. Students should be encouraged to make effective use of teacher feedback on their writing by attending tutorials, asking questions and responding to both oral and written feedback by revising problematic aspects of their writing and applying given feedback to their future assignments.

This study has provided some evidence indicating that the EAP course was effective in reducing the participants' use of the less effective writing strategy of grammar revising. The results of our research support the idea that teachers need to make students aware of the importance of focusing on content and organisation prior to engaging with the surface revisions in their written 
texts. Also, teachers need to emphasize that a backtracking strategy might assist students considerably when reflecting on what they have already produced. Rereading their own assignments a number of times might give L2 writers multiple opportunities to identify the inconsistencies which they did not notice the first time. Finally, teachers should also encourage students to reread their texts to devise new ideas as well as to critically evaluate what they have written.

An important methodological contribution of our study lies in the combination of the two qualitative research tools to enable L2 learners to reflect on their own writing progress in the learning journals and to shed light on their thought processes in the interviews. A number of interesting findings generated as a result of this study appear to be particularly relevant to presessional summer programmes. Learners' increased use of such writing strategies, like engaging extensively with the scholarly literature, reading critically the exemplars of exceptionally well-written student essays, rereading what they have already written, and seeking tutor support, seem to inform second language writing research by providing useful insights into learners' perceptions of the effective writing strategies. 


\section{References}

Bernard, S. H. (2000). Social research methods: Qualitative and quantitative approaches. Sage.

Bitchener, J. (2017). Creating an effective argument in different academic genres: A scaffolded approach. In J. Bitchener, N. Storch, \& W. Rosemary (Eds.), Teaching writing for academic purposes to multilingual students: Instructional approaches (pp. 84-98). Routledge.

Bitchener, J., \& Basturkmen, H. (2006). Perceptions of the difficulties of postgraduate L2 thesis students writing the discussion section. Journal of English for Academic Purposes, 5(1), 4-18. https://doi.org/10.1016/j.jeap.2005.10.002

Borg, S. (2001). The research journal: A tool for promoting and understanding researcher development. Language Teaching Research, 5(2), 156-177. https://doi.org/10.1177/136216880100500204

British Educational Research Association. (2011). Ethical guidelines for educational research. https://www.bera.ac.uk/researchers-resources/publications/ethical-guidelines-foreducational-research-2011

Bryman, A. (2003). Quantity and quality in social research ( $2^{\text {nd }}$ ed. $)$. Routledge.

Cathro, V., O'Kane, P., \& Gilbertson, D. (2017). Assessing reflection: Understanding skill development through reflective learning journals. Education \& Training, 59(4), 427442.

https://doi.org/10.1108/ET-01-2017-0008

Creswell, J. W., \& Plano Clark, V. L. (2011). Designing and conducting mixed methods research $\left(2^{\text {nd }}\right.$ ed. $)$. Sage.

Creswell, J. W., Plano Clark, V. L., Gutmann, M. L., \& Hanson, W. E. (2003). Advanced mixed methods research designs. In A. Tashakkori \& C. Teddlie (Eds.), Handbook of mixed methods in social and behavioral research (pp. 209-240). Sage.

Csizér, K., \& Tankó, G. (2015). English majors' self-regulatory control strategy use in academic writing and its relation to L2 motivation. Applied Linguistics, 38(3), 1-20.

Evans, S., \& Green, C. (2007). Why EAP is necessary: A survey of Hong Kong tertiary students. Journal of English for Academic Purposes, 6(1), 3-17. https://doi.org/10.1016/j.jeap.2006.11.005

Ferris, D. (2010). Second language writing research and written corrective feedback in SLA: Intersections and practical applications. Studies in Second Language Acquisition, 32(2), 181-201. https://doi.org/10.1017/S0272263109990490

Ferris, D. (2017). Facilitating academic language development. In J. Bitchener, N. Storch, \& R. Wette (Eds.), Teaching writing for academic purposes to multilingual students: Instructional approaches (pp. 145-167). Routledge.

Hanks, J. (2015). 'Education is not just teaching': Learner thoughts on Exploratory Practice. ELT Journal, 69(2), 117-128. https://doi.org/10.1093/elt/ccu063

Hanks, J. (2017). Integrating research and pedagogy: An exploratory practice approach. System, 68, 38-49. https://doi.org/10.1016/i.system.2017.06.012

Hinkel, E. (2004). Teaching academic ESL writing: Practical techniques in vocabulary and grammar. Erlbaum. 
Guo, X., \& Huang, L.-S. (2018). Are L1 and L2 strategies transferable? An exploration of the L1 and L2 writing strategies of Chinese graduate students. The Language Learning Journal, 48(6), 715-737. https://doi.org/10.1080/09571736.2018.1435710

Huang, L.-S. (2013). Cognitive processes involved in performing the IELTS speaking test: respondents' strategic behaviours in simulated testing and non-testing contexts. IELTS Research Report Series No. 1.

Hyland, K. (2016). Teaching and researching writing ( $3^{\text {rd }}$ ed.). Routledge.

Hyland, K., \& Hamp-Lyons, L. (2002). EAP: Issues and directions. Journal of English for Academic Purposes, 1(1), 1-12. https://doi.org/10.1016/S1475-1585(02)00002-4

Khaldieh, S. A. (2000). Learning strategies and writing processes of proficient vs. lessproficient learners of Arabic. Foreign Language Annals, 33(5), 522-533. https://doi.org/10.1111/j.1944-9720.2000.tb01996.x

Krause, K. (2001). The university essay writing experience: A pathway for academic integration during transition. Higher Education Research and Development, 20(2), 147-168. https://doi.org/10.1080/07294360123586

Kubota, R. (1998). An investigation of L1-L2 transfer in writing among Japanese university students: Implications for contrastive rhetoric. Journal of Second Language Writing, 7(1), 69-100. https://doi.org/10.1016/S1060-3743(98)90006-6

Kvale, S. (2003). The psychoanalytic interview as inspiration for qualitative research. In P. Camic, J. Rhodes, \& L. Yardley (Eds.), Qualitative research in psychology: Expanding perspectives in methodology and design (pp. 275-297). American Psychological Association.

Landis, J., \& Koch, G. (1977). The measurement of observer agreement for categorical data. Biometrics, 33(1), 159-174. https://doi.org/10.2307/2529310

Leedham, M. (2014). 'Enjoyable', 'okay', or 'like drawing teeth'? Chinese and British students' views on writing assignments in UK universities. Journal of Academic Writing, 4(1), 111. https://doi.org/10.18552/joaw.v4i1.128

Leki, I., \& Carson, J. G. (1994). Students' perceptions of EAP writing instruction and writing needs across the disciplines. TESOL Quarterly, 28(1), 81-101. https://doi.org/10.2307/3587199

Manchón, R. M. (2001). Trends in the conceptualization of second language composing strategies: A critical analysis. International Journal of English Studies, 1(2), 47-70.

Manchón, R. M. (2012). L2 Writing Development: Multiple Perspectives. de Gruyter Mouton.

Manchón, R. M. (2017). The multifaceted and situated nature of the interaction between language and writing in academic settings. Advancing research agendas. In $\mathrm{J}$. Bitchener, N. Storch, and R. Wette (Eds.), Teaching writing for academic purposes to multilingual students: Instructional approaches (pp. 183-200). Routledge.

Manchón, R. M., Roca de Larios, J., \& Murphy, L. (2000). An approximation to the study of backtracking in L2 writing. Learning and Instruction, 10(1), 13-35. https://doi.org/10.1016/S0959-4752(99)00016-X

Manchón, R. M., Murphy, L., \& Roca de Larios, J. (2007a). Lexical retrieval processes and strategies in second language writing: A synthesis of empirical research. International 
Journal of English Studies, 7(2), 149-174. Retrieved from https://revistas.um.es/ijes/article/view/49041

Manchón, R. M., Roca de Larios, J., \& Murphy, L. (2007b). A review of writing strategies: Focus on conceptualizations and impact of the first language. In A. Cohen, \& E. Macaro (Eds.), Language learner strategies: Thirty years of research and practice (pp. 229-250). Oxford University Press.

Mann, S. (2016). The research interview: Reflective practice and reflexivity in research processes. Palgrave Macmillan.

Marshall, S. (1991). A genre-based approach to the teaching of report-writing. English for Specific Purposes, 10(1), 3-13. https://doi.org/10.1016/0889-4906(91)90012-L

Mazgutova D., \& Kormos, J. (2015). Syntactic and lexical development in an intensive English for Academic Purposes programme. Journal of Second Language Writing, 29, 3-15. https://doi.org/10.1016/j.jslw.2015.06.004

Mu, C., \& Carrington, S. (2007). An investigation of three Chinese students' English writing strategies. TESL-EJ, 11(1), 1-23.

Myhill, D., \& Jones, S. (2007). More than just error correction: Students' perspectives on their revision processes during writing. Written Communication, 24(4), 323-343. https://doi.org/10.1177/0741088307305976

O'Malley, J. M., \& Chamot, A. U. (1990). Learning strategies in second language acquisition. Cambridge University Press.

Oxford, R. L. (1990). Language learning strategies: What every teacher should know. Newbury House.

Oxford, R. L. (2016). Toward a psychology of well-being for language learners: The "EMPATHICS" Vision. In P. McIntyre, T. Gregersen, \& S. Mercer. (Eds.), Positive psychology in second language acquisition (pp. 10-87). Multilingual Matters.

Paltridge, B. (2014). Genre and second language academic writing. Language Teaching, 47(3), 303-318. https://doi.org/10.1017/S0261444814000068

Paltridge, B. (2017). Context and the teaching of academic writing: Bringing together theory and practice. In J. Bitchener, N. Storch, \& R. Wette (Eds.), Teaching writing for academic purposes to multilingual students: Instructional approaches (pp. 9-23). Routledge.

Pecorari, D. (2016). Writing from sources, plagiarism and textual borrowing. In R. M. Manchón, \& P. K. Matsuda (Eds.), The handbook of second and foreign language writing (pp. 329-347). de Gruyter Mouton.

Petrić, B., \& Harwood, N. (2013). Task requirements, task representation, and self-reported citation functions: An exploratory study of a successful L2 student's writing. Journal of English for Academic Purposes, 12(2), 110-124. https://doi.org/10.1016/j.jeap.2013.01.002

Phakiti, A., \& Li, L. (2011). General academic difficulties and reading and writing difficulties among Asian ESL postgraduate students in TESOL at an Australian university. RELC Journal, 42(3), 227-264. https://doi.org/10.1177/0033688211421417

Reid, J. (2001). Advanced EAP writing and curriculum design: What do we need to know? In T. Silva, \& P. K. Matsuda (Eds.), On second language writing (pp. 143-160). Erlbaum. 
Richards, K. (2003). Qualitative inquiry in TESOL. Palgrave Macmillan.

Roca de Larios, J., Coyle, Y., \& Nicolás-Conesa, F. (2016). Focus on writers: Processes and strategies. In R. M. Manchón, \& P. K. Matsuda (Eds.), The handbook of second and foreign language writing (pp. 267-286). de Gruyter Mouton.

Rubin, H. J., \& Rubin, I. S. (2005). Qualitative interviewing: The art of hearing data (2nd ed.). Sage.

Ryan, G. W., \& Bernard, H. R. (2003). Techniques to identify themes. Field Methods, 15(1), 85-109. https://doi.org/10.1177/1525822X02239569

Silva, T. (1993). Toward an understanding of the distinct nature of L2 writing: The ESL Research and its implications. TESOL Quarterly, 27(4), 657-677. https://doi.org/10.2307/3587400

Storch, N., \& Tapper, J. (2009). The impact of an EAP course on postgraduate writing. Journal of English for Academic Purposes, 8(3), 207-223. https://doi.org/10.1016/j.jeap.2009.03.001

Taylor, C., \& Gibbs, G. R. (2010). How and what to code. Online QDA: Learning Qualitative Data Analysis on the Web.

https://web.archive.org/web/20170714073751/http:/onlineqda.hud.ac.uk/Intro QDA/h ow what to code.php

Tardy, C. M. (2017). The challenge of genre in the academic writing classroom: Implications for L2 writing teacher education. In J. Bitchener, N. Storch, \& R. Wette (Eds.), Teaching writing for academic purposes to multilingual students: Instructional approaches (pp. 69-83). Routledge.

Threlfall, S. J. (2014). E-journals: Towards critical and independent reflective practice for students in higher education. Reflective Practice, 15 (3), 317-332. https://doi.org/10.1080/14623943.2014.900012

Wallin, P., \& Adawi, T. (2017). The reflective diary as a method for the formative assessment of self-regulated learning. European Journal of Engineering Education, 43 (4), 507521. https://doi.org/10.1080/03043797.2017.1290585

Wette, R. (2017). L2 undergraduate students' learning to write using sources: A trajectory of skill development. In J. Bitchener, N. Storch, \& R. Wette (Eds.), Teaching writing for academic purposes to multilingual students: Instructional approaches (pp. 99-112). Routledge.

Whiting, L. (2008). Semi-structured interviews: Guidance for novice researchers. Nursing Standard, 22, 35-40. https://doi.org/10.7748/ns2008.02.22.23.35.c6420

Wolfersberger, M. (2003). L1 to L2 writing process and strategy transfer: A look at lower proficiency writers. Teaching English as a Second or Foreign Language, 7(2). http://tesl-ej.org/ej26/a6.html

Zhu, W. (2001). Interaction and feedback in mixed peer response groups. Journal of Second Language Writing, 10 (4), 251-276. https://doi.org/10.1016/S1060-3743(01)00043-1

Zhu, W. (2004). Faculty views on the importance of writing, the nature of academic writing, and teaching and responding to writing in the disciplines. Journal of Second Language Writing, 13 (1), 29-48. https://doi.org/10.1016/j.jslw.2004.04.004 


\section{Appendix A. Interview prompts}

Interview questions (Week 1)
How do you see yourself as a writer?
How do you feel when you write in English?
What kinds of writing do you expect to be
doing on the EAP programme?
doing on the EAP programme?

What is your usual method of writing in English? What steps do you follow when writing?

Did you ever get feedback on your writing? How did you feel about it and what did you do with it? Did you find the feedback useful?

What is your own method of checking or rewriting what you have written?

How are you trying to improve your writing in English?

\section{Interview questions (Week 4)}

Do you see yourself any differently from what you were at the beginning of the EAP programme?

Do you feel any different from what you felt at the beginning of the programme?

Have your expectations regarding the kinds of writing done on the EAP programme been met? Do you think the writing you have learned will help you on your degree programme?

Has your method of writing in English changed in 4 weeks? What steps do you follow now when writing?

How did you feel about the feedback you got on your writing on the EAP program? What did you do with it? Did you find useful? Why/why not?

Has your method of checking or rewriting what you have written changed in four weeks' time?

How are you trying to improve your writing in English after 4 weeks of studying on the EAP programme? 


\section{Appendix B. Learning journal prompts}

1. How did you feel when you wrote in English?

2. How did you compose your essay? Did you use any specific strategies when writing the essay?

3. Where did you get the information for writing (e.g., your own ideas, experiences, other peoples' experiences, books or other sources of information)?

4. Did you ever get stuck while writing/did you have to think hard? When did that happen and why? What did you do to get 'unstuck'/to find the way out?

5. What was your goal in terms of writing? Did you achieve your goal? If yes, how well did you achieve it? If not, why did you not achieve it?

6. What did you find was a problem for you in terms of writing? What were you trying to improve? What would you like to have done better?

7. Did you get a teacher feedback on your writing this week? What did you think of that? How did you feel about it? Did you find it helpful and understandable? Why/Why not?

9. What did you learn from the feedback you got this week?

10. How are you going to apply the feedback you got on this essay to your other written assignments? 


\section{Appendix C. Post-course interview transcript example}

Interviewee (I): How do you see yourself as a writer now after 4 weeks on EAP?

Participant $(\mathrm{P})$ : I think I feel better than before because I have practiced my writing for more than three weeks and get some knew knowledge about how to write well or write more academic.

I: How do you feel when you write now?

$\mathrm{P}$ : sometimes it is difficult to catch up some clear ideas to prove my main point, but other aspects, like how to write the Introduction or Conclusion and using the references correctly is better for me to write.

I: How does writing help you to learn the language?

P: writing includes not only the vocabulary and some paragraphing and some model sentences I can use in other skills, like listening and reading.

I: How does writing help you to develop language skills?

P: when I write my essay I can keep some useful sentences to help my reading and listening.

I: Have your expectations been met on the EAP programme?

Seeking tutor

support

P: yes, I think so, not all achieved but I can get better than before, I improved a lot in my writing. I can listen my tutor's advice and erm ... abandon some of my own drawbacks and keep on the advantages of writing, and read more academic essays and texts to help me finish my own essay. I hoped I could read and write more, but sometimes I was lazy and didn't reads more.

I: Imagine a new student has arrived on the EAP programme. How would you explain what good academic writing is?

P: it should have well-organised introduction and summary and body paragraphs should connect to key points listed at the beginning, and if they are some researches from other persons, we should write the references at the end of essay. Some referencing, paraphrasing, quotation and citation well. I have also learned the Introduction should include the key points, my own position and the route map.

I: Have your goals with regard to writing changed in 4 weeks on the EAP course?

P: before I hoped I can practice my English by the EAP course and improve my presentations by using spoken English well, but now I think English is not the only important thing to learn, but also my future degree course is very important to learn, so I need to acquire some knowledge to become familiar with my Major course. Sometimes I just don't know how to prove my evidence clearly, sometimes my examples are not supporting my main point. So, I look for some journal articles from which I can learn how to integrate evidence from the literature to my own essay. Reading various academic books and papers has helped me to become better at writing and I feel much more confident now.

I: Have your methods of writing changed in 4 weeks?

P: before I would write my essay from beginning to the end, but now I tend to write and revise more frequently written writing. I notice that reading again what I have just said helps. Thus, I can easily spot some mistakes or incomplete sentences. I think I should make a clear outline first, write an Introduction and then think 3-4 key topic sentences about my body paragraph and finish each paragraph and last I will complete my summary.

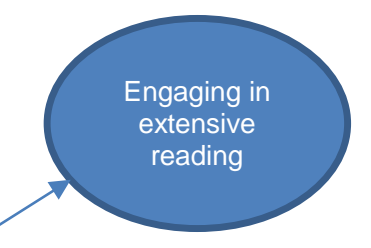


I: How do you feel about the feedback that you got on EAP?

P: I think it was suitable, erm ... useful for me. If I did something well, she would tell me, and if I didn't present my opinions clearly she would also tell me how to present it

I: What did you do with the feedback?

P: I will read it carefully and at the tutorial I would discuss it with my tutor. If just one paragraph is not very well, I would revise the paragraph and take some advice from my tutor.

I: Have you got your own method of checking and revising what you have written? Has it changed?

P: I think there are many useful methods in Gold Book, it can teach you some to be more mitigated when I present my own view. If I rewrite something I will sometimes ask my friends to see my paragraph and give me some advice on it. I think I learned it on the EAP course, my tutor also asked me to listen to other students' advice.

I: How are you trying to improve your writing in English?

P: I should read more academic essays and make some notes about the useful sentences and keep them down and use them for my next writing or essay. I can also add something from my Gold Book and if I need some advice to write I use the Gold Book as a source.

from my Gold Book and if I need some advice to write I use the Gold Book as a source. 